\title{
Social Equity and COVID-19: The Case of African Americans
}

\author{
James E. Wright II \\ Assistant Professor \\ Reubin O'D. Askew School of Public Administration and Policy \\ Florida State University \\ 656 Bellamy Building \\ Tallahassee, FL 32306-2250 \\ jwright4@fsu.edu \\ Cullen C. Merritt \\ Assistant Professor \\ Paul H. O’Neill School of Public and Environmental Affairs \\ Indiana University-Purdue University Indianapolis \\ 801 W. Michigan St., BS 4155 \\ Indianapolis, IN 46202 \\ merritt1@iupui.edu
}

Authors' copy

Forthcoming at Public Administration Review

Accepted May 23, 2020 


\title{
Social Equity and COVID-19: The Case of African Americans
}

\begin{abstract}
Emerging statistics demonstrate that COVID-19 disproportionately affects African Americans. The effects of COVID-19 for this population are inextricably linked to areas of systemic oppression and disenfranchisement, which are further exacerbated by COVID-19: (1) healthcare inequality; (2) segregation, overall health, and food insecurity; (3) underrepresentation in government and the medical profession; and (4) inequalities in participatory democracy and public engagement. Following a discussion of these issues, this article shares early and preliminary lessons and strategies on how public administration scholars and practitioners can lead in crafting equitable responses to this global pandemic to uplift the African American community.
\end{abstract}




\section{Social Equity and COVID-19: The Case of African Americans}

\section{Evidence for Practice}

- Prioritizing social equity can strongly position policymakers and public administrators to craft policy solutions and reverse administrative ills that uniquely harm African Americans during COVID-19.

- The development of a national, standardized data collection system that captures the demographic backgrounds of people infected with COVID-19 better positions government to equitably and efficiently distribute human, economic, and medical resources.

- An equitable and effective response to COVID-19 for African Americans requires government to partner with nonprofit organizations, including those led by African Americans and/or serving predominately African American communities.

- Specific strategies that may safeguard the ability of African Americans to vote include, but are not limited to, expanding opportunities for eligible Americans to register and vote remotely as well as adopting and extending paid time off for voting in low-skill professions.

- Addressing digital inequality is fundamental to the ability of African Americans to gain access to potentially life-saving information necessary to mitigate the spread of COVID-19 and civically engage to advance causes salient to the African American community. 


\section{Social Equity and COVID-19: The Case of African Americans}

\section{Introduction}

COVID-19 has led to sharp disruptions in financial markets in the United States, a shift in activities in organizations across industries and sectors, and changes in daily life for all Americans. Federal, state, and local leaders have responded by adopting practices and protocols geared at mitigating the spread of the virus, including the adoption of social distancing rules, curfews, and mandatory stay-at-home orders. Despite human, economic, and medical resources being distributed to fight this virus, marginalized and underrepresented populations remain particularly vulnerable. These vulnerable communities include populations such as low-income individuals, people of color, indigenous people, and senior citizens. Of these vulnerable populations, preliminary data suggests that COVID-19 is infecting and killing African Americans in the United States at disproportionately high rates. According to an April 7, 2020 New York Times article, "Initial indications from a number of places...are alarming enough that policymakers say they must act immediately to stem potential devastation in black communities."

Social equity, the fourth pillar of public administration, must be considered in public service responses to COVID-19 — including in ways that eliminate institutional racism. Defined as "those established laws, customs and practices which systematically reflect and produce racial inequalities in American society... whether or not the individuals maintaining those practices have racist intentions" (Jones 1972, 131), institutional racism impacts the cultural, economic, political, cognitive, and organizational experiences of African Americans (Ward and Rivera 2014). Given the multifaceted nature of institutional racism, prioritizing social equity can strongly position policymakers and public administrators to craft policy solutions and reverse administrative ills that uniquely harm African Americans during the current global health crisis. 


\section{Social Equity and COVID-19: The Case of African Americans}

According to the National Academy of Public Administration (NAPA), social equity encompasses the

"fair, just and equitable management of all institutions serving the public directly or by contract, and the fair and equitable distribution of public services and the implementation of public policy and the commitment to promote fairness, justice, and equity in the formation of public policy." (Johnson \& Svara, 2015)

McCandless and Guy (2012) highlight that social equity has progressed from a philosophical (social contract) to a structural (constitutional) to an administrative (social equity) concern. With a robust and growing scholarship surrounding social equity (Collins and Gerber, 2008; Gooden and Portillo, 2011; Norman-Major, 2011; Rice, 2004; Riccucci, 2009; Riccucci and Van Ryzin 2017, Smith and Fernandez, 2010; Wooldridge and Gooden, 2009; Frederickson 1990), the COVID-19 pandemic presents a unique opportunity to further the promise of public administration's fourth pillar.

In this article, we highlight areas of systemic oppression and disenfranchisement for African Americans that are inextricably linked to and further exacerbated by COVID-19. These areas include (1) healthcare inequality, (2) segregation, overall health, and food insecurity, (3) underrepresentation in government and the medical profession, and (4) inequalities in participatory democracy and public engagement. After describing these inequities, this article shares early and preliminary lessons and strategies on how public administration scholars and practitioners can lead in crafting equitable responses to these issues to uplift African Americans during (and beyond) this global pandemic.

\section{Areas of Systemic Oppression and Disenfranchisement in the African American Community}

Healthcare Inequality 


\section{Social Equity and COVID-19: The Case of African Americans}

Racial/ethnic disparities in health care quality in the United States make African Americans uniquely vulnerable to COVID-19. These disparities intensify when accounting for socioeconomic status (Assari, 2018; Chen et al., 2016; Escarce and Puffer, 1997; Fiscella, Franks

\& Clancy, 1998; Newacheck, Hughes, \& Stoddard, 1996; Richardson and Norris, 2010). Despite African Americans having some of the worst health outcomes in the country, White Americans have better access to resources and treatment within the healthcare system essential to leading a healthy lifestyle (Schwartz et al., 1990; Woolhandler et al., 1985). For example, Blacks compared to Whites are seen by less specialists (Murphy et al., 2009; Nguyen et al., 2010), Blacks compared to Whites are more likely to die from diabetes from lack of intensive care (Heisler et al., 2003) and Blacks have the highest rate of cardiovascular disease (CDV) mortality (McGruder et al., 2004; Howard and Howard, 2001).

Racial/ethnic disparities in relation to healthcare extend to the workplace, where a high rate of African Americans occupy low-wage jobs, in which insurance coverage is either unavailable or unaffordable (Brown et al., 2001; Moss and Tilly, 2001) and paid sick leave is limited. In 2015, compared with Whites, African Americans were less likely to have employerprovided private coverage because of income (Chen, Bustamante \& Tom, 2015). As a consequence, African Americans have less access to a regular health care provider (Hargraves 2002) and are more likely to rely heavily on hospital emergency rooms (Roby, Nicholson, \& Kominski, 2009). In addition to these transactions not being cost-effective, the surges in emergency room care for COVID-19 patients may create additional barriers to healthcare access for African Americans. Segregation, Overall Health, and Food Insecurity 


\section{Social Equity and COVID-19: The Case of African Americans}

Racial residential segregation occurs when two or more groups of people are spatially separated (Massey and Denton, 1988) and occupy different areas of the same city, a pattern which can be shaped by discriminatory outside forces and/or the social organization of the group itself. Practices across the country such as redlining, exclusionary zoning, and racial covenants created highly segregated neighborhoods in which Blacks were explicitly or implicitly denied the ability to rent or buy homes in White neighborhoods. Traditionally up until 1990, large metropolitan areas exhibited the highest level of segregation (Massey and Denton 1989, 1993). However, recent literature has shown that levels of segregation in the United States have decreased in the past twenty years (Del Río and Olga, 2015; Lee, 2016). Despite these gains, residential segregation between Blacks and Whites still presents persistent and heightened gaps that have not been ameliorated (Ellis, Wright \& Holloway, 2018). In 2010, one-half of Black metropolitan residents lived in areas with high levels of segregation or in hyper-segregated metropolitan areas (Massey and Tannen, 2015). Although most immigrant groups have experienced residential segregation in the United States, no immigrant group has ever lived under the levels of segregation that currently exist for African Americans (Massey, 1993).

As a result of residential segregation, African Americans have lower educational attainment (Goldsmith, 2009; Mayer, 2002; Quillian, 2014), more negative interactions with the police (Grove et al., 2018; Renauer, 2012) and increased mortality rates (Collins and Williams, 1998; Fang et al., 1998). Segregation has also resulted in increased health challenges for African Americans. In particular, African Americans who live in highly segregated areas have generally lower health outcomes (Chang, 2006; Corral et al., 2012; Polednak, 1996). Intergenerational research has documented that African Americans living in segregated areas have limited healthy 


\section{Social Equity and COVID-19: The Case of African Americans}

food options and the increased poverty has contributed to adverse health effects on Black adults and children (Moore and Diez Roux, 2006; Zenk et al., 2005).

Black neighborhoods are some of the poorest census tracts in the United States (Duncan et al., 2013; Jargowsky, 1984), and food insecurity poses a serious risk to low income households. High levels of poverty are associated with a lack of healthy food options. Research has also shown that people from low income backgrounds and poor census tracts cannot afford healthy food options (Mooney, 1990). As a result, these individuals tend to buy more processed food and smaller quantities of food because of financial restrictions and lack of disposable income (Smith, Ng \& Popkin, 2013). Households that are food insecure have higher levels of malnutrition as well as reduced health and quality of life (Campbell, 1991).

While much of the literature on food insecurity has extensively examined its impact on low income households, several researchers have explored food insecurity exclusively in African American communities. Zenk (2005) found that predominantly African American communities are, on average, 1.1 miles farther away from a supermarket, even when controlling for income between Black and White neighborhoods. In a study conducted in Mississippi, North Carolina, Maryland, and Minnesota, Morland et al. (2002) found that supermarkets were four times more common in predominantly White neighborhoods compared to Black neighborhoods and convenience stores attached to gas stations were more common in Black neighborhoods. Similar results were confirmed in Bower et al., (2014) that, at equal levels of poverty, Black census tracts had the fewest supermarkets and White tracts had the most. Even when Black neighborhoods and families have access to high energy foods, such as fruits and vegetables, they are sold at prices too high for families to afford. Rehm, Monsivais, and Drewnowski (2011) found that Black 


\section{Social Equity and COVID-19: The Case of African Americans}

families were "priced out" of meeting dietary guidelines that include foods such as fruits, vegetables, and whole grains.

Residential segregation and the food insecurity that results from it make buying food for an extended period during COVID-19 almost impossible for many African Americans, particularly those living in poor census tracts. Even when this population can buy food, lack of disposable income means they must settle for low-quality foods, which lack proper nutritional content.

\section{Underrepresentation in Government and the Medical Profession}

Underrepresentation of African Americans reverberates throughout the medical profession (e.g., lack of African American doctors) (Garces and Mickey-Pabello 2016) and in state and local governments (Sabharwal and Geva-May 2013; Riccucci and Saidel 1997), posing implications for the equitable response to COVID-19 for African Americans. For example, there is growing concern over inequities produced through unconscious attitudes or implicit biases that place African Americans at a measurable disadvantage. This disadvantage is borne out when it comes to determining who should be tested for COVID-19 or when medical professionals downplay - or altogether ignore - the symptoms of African Americans (see Blair, Havranek, Price, Hanratty, Fairclough, Farley, Hirsh, Steiner 2012). With a lack of African American representation in government, policy solutions by state and local officials concerning COVID-19 testing have unintended consequences.

For example, multiple states have administered drive-thru testing; however, African American households are three times as likely as White households to be without a car (National Equity Atlas 2015) making these facilities less accessible for African Americans. The percentage of African Americans without a car in cities, such as Chicago, Atlanta, and Milwaukee, ranges 


\section{Social Equity and COVID-19: The Case of African Americans}

from around 30\% to 50\% (National Equity Atlas 2015). Health care inequities are also, in part, products of underrepresentation and are powerful correlates of medical mistrust among African Americans (Hammond 2010). This mistrust leads to psychosocial responses to health care, where African Americans may ignore individualized medical advice or more general recommended practices intended to mitigate the spread of COVID-19, such as social distancing.

Inequalities in Participatory Democracy and Public Engagement

African Americans are particularly vulnerable to voter suppression (Blessett 2015), and the COVID-19 pandemic may intensify the fight over voting rights. In the Jim Crow South, African Americans faced bullets, beatings, lynching, and more for seeking to exercise their right to vote (Anderson 2020). "Over the years the weapon has gotten much more sophisticated, the language a bit more genteel, but the goal has been just the same: maintain power by keeping American citizens away from the voting booth" (Anderson 2020., p. 1). Modern-day voter suppression tactics, according to Blessett (2015), are often perpetuated by color-blind policies that "do not explicitly identify or articulate a relationship to any specific racial or ethnic group, but produces racially disproportionate outcomes after implementation," such as: financial hardship, mass confusion, limited access to the ballot, dilution of the vote geographically, or use of subjective measures of eligibility (p. 17). Several state-level legislative efforts, amid the COVID-19 pandemic, related to election administration illustrate Blessett's (2015) point.

For example, the Kentucky legislature passed a bill which, if made law, would introduce a new photo identification requirement ahead of the November 2020 election, despite many offices that issue photo IDs being closed per the recommendation of the state's public health officials. Wisconsin held its primary election in April, even though voting conflicted with an ongoing stay-at-home order issued by Governor Tony Evers, who criticized the state legislature 


\section{Social Equity and COVID-19: The Case of African Americans}

for forcing citizens to "choose between their health and their vote". According to Molly McGrath of the American Civil Liberties Union, tactics like those in Kentucky and Wisconsin are "voter suppression on steroids.... a lot of the same communities and the same people who are impacted by voter suppression are now impacted by this pandemic" (Perrett 2020). Similarly, in a Supreme Court order - the first related to COVID-19—-blocking a lower court ruling that gave Wisconsin voters an extra six days to submit their primary election ballots, Justice Ruth Bader Ginsberg dissented, stating, "While I do not doubt the good faith of my colleagues, the Court's order, I fear, will result in massive disenfranchisement." (Republican National Committee v. Democratic National Committee 2020).

Voting, while fundamental to participatory democracy, is only one aspect of public engagement (Nabatchi 2012). Public engagement (a term used interchangeably with activities, such as civic engagement, collaborative governance, and community engagement) has gained momentum over the past decade because of people's commitment to building community, enhancing the production and delivery of public services, addressing complex governance problems, and reducing democratic and citizen deficits (Nabatchi and Amsler 2014; Bingham, Nabatchi, and O'Leary 2005; Merritt 2019). Local elected and administrative officials, nonprofit organizations, and neighborhood associations are often sponsors or conveners of public engagement (Nabatchi and Amsler 2014). For African Americans, public engagement can create pathways for civic dialogue on issues, such as: politics, public policy, or race relations, and subsequently serve as a "launch pad for a variety of collective actions" on issues salient to the African American community (Walsh 2007, p. 241). These issues can include greater diversity in police hiring (Walsh 2007), improved race relations (Leighninger 2006), and creating antidiscrimination laws in public schools (Walsh 2007). Nevertheless, African Americans often 


\section{Social Equity and COVID-19: The Case of African Americans}

experience difficulties in gaining access to public engagement forums (Walsh 2007; see Jacobs, Cook, and Delli Carpini 2009); even when access is attained, they may still systemically struggle to leverage these forums to engage heterogeneous populations in constructive conversations on issues salient to the African American community, such as race and racism (Leighninger 2006; Mendelberg 2002; Mendelberg and Oleske 2000).

Inequalities in public engagement can be mitigated through social capital (Jacobs et al. 2009; Leighninger 2006), defined as "connection among individuals--social networks and the norms of reciprocity and trustworthiness that arise from them" (Putnam 2000, p. 19). Social capital "calls attention to the fact that civic virtue is most powerful when embedded in a sense network of reciprocal social relations (Putnam 2000, p.19). For African Americans, faith-based organizations are among the organized entities central to social capital and public engagement (Kaiser 2015; Putnam 2000; Schneider 2009). According to Putnam,

"the church is the oldest and most resilient social institution in black America, not least because it was traditionally the only black-controlled institution of a historically oppressed people...The black religious tradition distinctively encourages mixing religion and community affairs and invigorated civic activism. Both during and after the civil rights struggle, church involvement among blacks has been strongly associated with civic engagement, in part because the church provides a unique opportunity for blacks to exercise civic skills". (p. 68).

Faith-based organizations also embed conveners of public engagement forums within networks from which they can engage in the targeted recruitment of African American participants (see Ryfe and Stalsburg 2012). Given state action (e.g., city-wide shutdowns) and medical recommendations (e.g., social distancing, self-quarantining) intended to mitigate the spread of COVID-19, this virus threatens to disrupt direct access to networks on which African Americans have long relied as primary means for social capital as well as disproportionately 


\section{Social Equity and COVID-19: The Case of African Americans}

jeopardize their ability to establish lasting influence in collaborative governance, civic dialogue, and other forms of public engagement.

\section{Responding Equitably to COVID-19: The Role of Public Administration Scholars and Practitioners}

To date, the COVID-19 pandemic has disproportionately affected African Americans and requires public administration scholars and practitioners to lead in crafting equitable responses to uplift this population while also mitigating the spread of this disease. Below we offer preliminary strategies that might help address the areas of systemic oppression and disenfranchisement for African Americans outlined earlier in this article, all of which are further exacerbated by COVID-19. Our strategies center on (1) collecting and releasing demographic data related to COVID-19, (2) engaging nonprofit organizations led by African Americans, (3) establishing election contingency plans that curtail voter suppression, and (4) reducing digital inequality, which presents barriers to public engagement and social capital among African Americans.

There are multiple organizations in the United States that track the number of COVID-19 cases by day, week, and month. At the state level, each Department of Health (or equivalent) is able to identify the number of COVID-19 cases. Despite the increased data collection efforts, there is no standard federal or state-level collection of data that tracks COVID-19 cases by demographics. Ideally, the Center for Disease Control would collect this data to create a national standardized data collection system to capture demographics of people infected with COVID-19. By collecting this data at the federal level, it would motivate states to be engaged with data collection efforts and alleviate some of the financial burden states may face maintaining this data over an extended period. Only a handful of states (California, Illinois, Michigan, North Carolina, South Carolina, and Wisconsin) have been collecting and releasing racial and ethnic data to the public, which shed light on the groups most susceptible to COVID-19. Preliminary data from 


\section{Social Equity and COVID-19: The Case of African Americans}

California, Illinois, Michigan, Wisconsin, and South Carolina indicates that African Americans are overrepresented in both the number of cases and deaths caused by COVID-19. According to the New York Times, about 70\% of the people in Louisiana who have died are African American, though only a third of the state's population is African America. Similarly, according to ProPublica, in Milwaukee County, Wisconsin, African American residents are 2.5 times more likely to die from COVID-19 than population data would suggest. If these numbers are representative of the entire nation, it is imperative that states release COVID-19 demographic data. Any response by policymakers to COVID-19 must include the collection of data on COVID-19 by demographics that include race, ethnicity, gender, sex, income, and poverty. By collecting this data, the government can then identify which populations need the most attention in addressing COVID-19. They can then efficiently distribute human, economic, and medical resources to help alleviate any inequities that exist in states and localities.

Nonprofits have increasingly played a role in service delivery for local and state governments (Cheng, 2019; Feiock, \& Jang, 2009; Guo, 2010, Lamothe \& Lamothe, 2006). While all nonprofits are mission-driven and goal oriented, there are distinct social and cultural qualities of nonprofits that are led by African Americans and serve predominantly African American communities. These nonprofits are engaged in the community building process and are more trusted by the communities they serve (Rivera \& Erlich, 1998). Gooden, Evans, and Pang (2018) found that nonprofits led by African Americans who serve their population were highly invested in the long-term success of the local community. They also noted that cultural considerations are embedded in organizational leadership in these nonprofits (Gooden et al. 2018). An equitable and effective response to COVID-19 for African Americans requires governments and local leaders to partner with these nonprofits to ensure that the most vulnerable 


\section{Social Equity and COVID-19: The Case of African Americans}

are being served. Furthermore, governments must be intentional about communicating and crafting solutions together with these nonprofits and their leaders, which are culturally entrenched in their communities.

State governments should establish election contingency plans amid COVID-19 to protect the accessibility, integrity, and security of the electoral process (Root 2020). Specific strategies that may safeguard the ability of African Americans to vote include, but are not limited to, expanding opportunities for eligible Americans to register remotely (e.g., online voter registration and establishing secure voter-registration drop boxes conveniently located across vulnerable communities). Additionally, states can expand opportunities for eligible voters to vote from home or at designated quarantine locations (e.g., offering vote-by-mail opportunities), and adopting and extending paid time off for voting in low-skill professions (Root 2020; see Blessett 2015; Moynihan and Herd 2010), ideally in ways that do not elevate administrative burdens (Herd and Moynihan 2019). Mitigating voter suppression may also have positive implications for greater African American representation in elective bodies responsible for designing public policies (Anderson 2018), including those pertaining to election administration. Public administration scholars can play a role in this area by conducting research to identify the best practices for formalizing and executing election contingency plans that simultaneously curtail voter suppression and position governments to equitably respond to future pandemics.

Lastly, while governments have leveraged the internet and social media technologies to foster public engagement (Nabatchi and Mergel 2010; Leighninger 2011; Young 2020), they have arguably dedicated less attention to the digital divide or digital inequality in access to computers, high-speed internet, and technology (Norris 2001; Mossberger, Tolbert, and Stansbury 2003), experienced by racial and ethnic minorities (Perrin and Turner 2019). African 


\section{Social Equity and COVID-19: The Case of African Americans}

Americans will be unable to gain access to critical, potentially life-saving information necessary to mitigate the spread of COVID-19—-let alone civically engage_-if this digital divide persists. Moreover, addressing digital inequality is fundamental to the ability of African Americans to cultivate social capital in ways that improve access to and quality of healthcare as well as trust in physicians (Robinson et al., 2015). Building on the work of Tolbert, Mossberger, and McNeal (2008) and Mossberger, Tolbert, and Stansbury (2003), digital inequality requires additional scholarly attention to understand how African Americans can enhance their social capital to a degree necessary to substantively participate in public engagement as well as access quality healthcare in a world defined by virtual connectedness amid COVID-19.

\section{Conclusion}

COVID-19 presents unique challenges to public administrators in the United States, who are rushing to mitigate the spread of the virus, minimize the death toll, and provide the necessary resources to their communities. As the importance of effective public administration amid COVID-19 grows, so too must the discipline's commitment to advancing social equity through public policy creation and implementation_-particularly for populations, such as African Americans, disproportionately affected by this global pandemic. As Blessett and colleagues (2019) state, public administration scholars and practitioners "must engage in intentional, active, and ethical efforts to serve and safeguard all people, especially the most vulnerable in our society" (p.296). In this sense, the discipline's commitment to crafting equitable responses to COVID-19 to uplift African Americans is an ethical imperative. We hope the preliminary strategies offered in this article not only advance this imperative in practice, but foster additional scholarship and dialogue on issues at the intersection of social equity, COVID-19, and the African American community. 


\section{Social Equity and COVID-19: The Case of African Americans}

\section{Case cited}

Republican National Committee v. Democratic National Committee, 589 U. S.

(2020)

\section{References}

Anderson, C. (2018). One person, no vote: How voter suppression is destroying our democracy. Bloomsbury Publishing USA.

Anderson, C. (2020). Republicans Could Use the Coronavirus to Suppress Votes Across the Country. This Week We Got a Preview. TIME. Accessed online.

Assari, S. (2018, March). The benefits of higher income in protecting against chronic medical conditions are smaller for African Americans than whites. In Healthcare (Vol. 6, No. 1, p. 2). Multidisciplinary Digital Publishing Institute.

Bingham, L. B., Nabatchi, T., \& O'Leary, R. (2005). The new governance: Practices and processes for stakeholder and citizen participation in the work of government. Public administration review, 65(5), 547-558.

Blair, I. V., Havranek, E. P., Price, D. W., Hanratty, R., Fairclough, D. L., Farley, T., ... \& Steiner, J. F. (2013). Assessment of biases against Latinos and African Americans among primary care providers and community members. American journal of public health, 103(1), 92-98.

Blessett, B. (2015). Disenfranchisement: Historical underpinnings and contemporary manifestations. Public Administration Quarterly, 3-50.

Blessett, B., Dodge, J., Edmond, B., Goerdel, H. T., Gooden, S. T., Headley, A. M., ... \& Williams, B. N. (2019). Social equity in public administration: A call to action. Perspectives on Public Management and Governance, 2(4), 283-299.

Bower, K. M., Thorpe Jr, R. J., Rohde, C., \& Gaskin, D. J. (2014). The intersection of neighborhood racial segregation, poverty, and urbanicity and its impact on food store availability in the United States. Preventive medicine, 58, 33-39.

Browne, I., Hewitt, C., Tigges, L., \& Green, G. (2001). Why does job segregation lead to wage inequality among African Americans? Person, place, sector, or skills?. Social Science Research, 30(3), 473-495. 


\section{Social Equity and COVID-19: The Case of African Americans}

Campbell, C. C. (1991). Food insecurity: a nutritional outcome or a predictor variable?. The Journal of nutrition, 121(3), 408-415.

Chang, V. W. (2006). Racial residential segregation and weight status among US adults. Social science \& medicine, 63(5), 1289-1303.

Chen, J., Vargas-Bustamante, A., Mortensen, K., \& Ortega, A. N. (2016). Racial and ethnic disparities in health care access and utilization under the Affordable Care Act. Medical care, 54(2), 140.

Cheng, Y. (2019). Exploring the role of nonprofits in public service provision: moving from coproduction to cogovernance. Public Administration Review, 79(2), 203-214.

Collins, B. K., \& Gerber, B. J. (2008). Taken for granted? Managing for social equity in grant programs. Public Administration Review, 68(6), 1128-1141.

Collins, C. A., \& Williams, D. R. (1999). Segregation and mortality: The deadly effects of racism? Sociological Forum, 14(3), 495-523.

Corral, I., Landrine, H., Hao, Y., Zhao, L., Mellerson, J. L., \& Cooper, D. L. (2012). Residential segregation, health behavior and overweight/obesity among a national sample of African American adults. Journal of Health Psychology, 17(3), 371-378.

Del Río, Coral, and Olga Alonso-Villar. "The evolution of occupational segregation in the United States, 1940-2010: Gains and losses of gender-race/ethnicity groups." Demography 52, no. 3 (2015): 967-988.

Duncan, D. T., Kawachi, I., White, K., \& Williams, D. R. (2013). The geography of recreational open space: Influence of neighborhood racial composition and neighborhood poverty. Journal of Urban Health, 90(4), 618-631.

Ellis, M., Wright, R., Holloway, S., \& Fiorio, L. (2018). Remaking white residential segregation: metropolitan diversity and neighborhood change in the United States. Urban geography, 39(4), 519-545.

Escarce, J. J., \& Puffer, F. W. (1997). Black-white differences in the use of medical care by the elderly: a contemporary analysis (pp. 183-209). Washington, DC: National Academy Press. 


\section{Social Equity and COVID-19: The Case of African Americans}

Fang, J., Madhavan, S., Bosworth, W., \& Alderman, M. H. (1998). Residential segregation and mortality in New York City. Social Science \& Medicine, 47(4), 469-476

Feiock, R. C., \& Jang, H. S. (2009). Nonprofits as local government service contractors. Public Administration Review, 69(4), 668-680.

Fiscella, K., Franks, P., \& Clancy, C. M. (1998). Skepticism toward medical care and health care utilization. Medical care, 180-189.

Frederickson, H. G. (1990). Public administration and social equity. Public Administration Review, 50(2), 228-37.

Garces, L. M., \& Mickey-Pabello, D. (2015). Racial diversity in the medical profession: The impact of affirmative action bans on underrepresented student of color matriculation in medical schools. The Journal of higher education, 86(2), 264-294.

Goldsmith, P. R. (2009). Schools or neighborhoods or both? Race and ethnic segregation and educational attainment. Social Forces, 87(4), 1913-1941.

Gooden, S. T., Evans, L. L., Perkins, M. L., Gooden, C., \& Pang, Y. (2018). Examining youth outcomes of African American-led nonprofits. Nonprofit and Voluntary Sector Quarterly, 47(4_suppl), 34S-54S.

Gooden, S., \& Portillo, S. (2011). Advancing social equity in the Minnowbrook tradition. Journal of Public Administration Research and Theory, 21(suppl_1), i61-i76.

Gooden, S., Evans, L., \& Pang, Y. (2018). Making the invisible visible in nonprofit courses: A case study of African American-led nonprofits. Journal of Public Affairs Education, 24(4), 490-517.

Grove, M., Ogden, L., Pickett, S., Boone, C., Buckley, G., Locke, D. H., ... \& Hall, B. (2018). The legacy effect: Understanding how segregation and environmental injustice unfold over time in Baltimore. Annals of the American Association of Geographers, 108(2), 524537.

Guo, B. (2010). Beyond the public safety net: The role of nonprofits in addressing material hardship of low-income households. Nonprofit and Voluntary Sector Quarterly, 39(5), 784-801. 


\section{Social Equity and COVID-19: The Case of African Americans}

Guy, M. E., \& McCandless, S. A. (2012). Social equity: Its legacy, its promise. Public Administration Review, 72(s1), S5-S13.

Hammond, W. P. (2010). Psychosocial correlates of medical mistrust among African American men. American journal of community psychology, 45(1-2), 87-106.

Hargraves, J. L. (2002). The insurance gap and minority health care, 1997-2001. Washington, DC: Center for Studying Health System Change.

Heisler, M., Smith, D. M., Hayward, R. A., Krein, S. L., \& Kerr, E. A. (2003). Racial disparities in diabetes care processes, outcomes, and treatment intensity. Medical care, 1221-1232.

Herd, P., \& Moynihan, D. P. (2019). Administrative burden: Policymaking by other means. New York: Russell Sage Foundation.

Howard, G., \& Howard, V. J. (2001). Ethnic disparities in stroke: the scope of the problem. Ethnicity \& disease, 11(4), 761-768.

Jacobs, L.R., Cook, F. L., \& Carpini, M. X. D. (2009). Talking together: Public deliberation and political participation in America. Chicago: University of Chicago Press.

Jargowsky, P. A. (1994). Ghetto poverty among blacks in the 1980s. Journal of Policy Analysis and Management, 13(2), 288-310.

Johnson, N. J., \& Svara, J. H. (2015). Justice for All: Promoting Social Equity in Public Administration: Promoting Social Equity in Public Administration. Routledge.

Jones, J.M. Prejudice and racism. Reading, MA: Addison-Wesley.

Kaiser, A. A. (2015). Faith-based organizations: A vehicle for cross-cultural relationship building. Journal of Religion \& Spirituality in Social Work: Social Thought, 34(3), 265284.

Lamothe, S., \& Lamothe, M. (2006). The dynamics of local service delivery arrangements and the role of nonprofits. Intl Journal of Public Administration, 29(10-11), 769-797.

Lee, K. O. (2016). Temporal dynamics of racial segregation in the United States: An analysis of household residential mobility. Journal of Urban Affairs. 


\section{Social Equity and COVID-19: The Case of African Americans}

Leighninger, M. (2011). Citizenship and governance in a wild, wired world: How should citizens and public managers use online tools to improve democracy?. National Civic Review, 100(2), 20-29.

Leighninger, M., 2006. The next form of democracy: How expert rule is giving way to shared governance-and why politics will never be the same. Nashville:Vanderbilt University Press.

Massey, D. S., \& Denton, N. A. (1989). Hypersegregation in US metropolitan areas: Black and Hispanic segregation along five dimensions. Demography, 26(3), 373-391.

Massey, D. S., \& Denton, N. A. (1993). American apartheid: Segregation and the making of the underclass. Harvard University Press.

Massey, D. S., \& Denton, N. A. (1998). The elusive quest for the perfect index of concentration: Reply to Egan, Anderton, and Weber. Social Forces, 76(3), 1123-1133.

Massey, D. S., \& Tannen, J. (2015). A research note on trends in black hypersegregation. Demography, 52(3), 1025-1034.

Mayer, S. E. (2002). How economic segregation affects children's educational attainment. Social forces, 81(1), 153-176.

McGruder, H. F., Malarcher, A. M., Antoine, T. L., Greenlund, K. J., \& Croft, J. B. (2004). Racial and ethnic disparities in cardiovascular risk factors among stroke survivors: United States 1999 to 2001. Stroke, 35(7), 1557-1561.

Mendelberg, T. (2002). The deliberative citizen: Theory and evidence. Political decision making, deliberation and participation, 6(1), 151-193.

Mendelberg, T., \& Oleske, J. (2000). Race and public deliberation. Political Communication, $17(2), 169-191$.

Merritt, C. C. (2019). What Makes an Organization Public? Managers' Perceptions in the Mental Health and Substance Abuse Treatment System. The American Review of Public Administration, 49(4), 411-424.

Mooney, C. (1990). Cost and availability of healthy food choices in a London health district. Journal of Human Nutrition and Dietetics, 3(2), 111-120. 


\section{Social Equity and COVID-19: The Case of African Americans}

Moore, L. V., \& Diez Roux, A. V. (2006). Associations of neighborhood characteristics with the location and type of food stores. American journal of public health, 96(2), 325-331.

Morland, K., Wing, S., Roux, A. D., \& Poole, C. (2002). Neighborhood characteristics associated with the location of food stores and food service places. American journal of preventive medicine, 22(1), 23-29.

Moss, P., \& Tilly, C. (2001). Stories employers tell: Race, skill, and hiring in America. Russell Sage Foundation.

Mossberger, K., Tolbert, C. J., \& Stansbury, M. (2003). Virtual inequality: Beyond the digital divide. Georgetown University Press.

Moynihan, D., \& Herd, P. (2010). Red tape and democracy: How rules affect citizenship rights. The American Review of Public Administration, 40(6), 654-670.

Murphy, M. M., Simons, J. P., Ng, S. C., McDade, T. P., Smith, J. K., Shah, S. A., ... \& Tseng, J. F. (2009). Racial differences in cancer specialist consultation, treatment, and outcomes for locoregional pancreatic adenocarcinoma. Annals of surgical oncology, 16(11), 2968.

Nabatchi, T. (2012). Putting the "public" back in public values research: Designing participation to identify and respond to values. Public Administration Review, 72(5), 699-708.

Nabatchi, T., \& Amsler, L. B. (2014). Direct public engagement in local government. The American Review of Public Administration, 44(4_suppl), 63S-88S.

Nabatchi, Tina, and Ines Mergel. 2010. Participation 2.0: Using Internet and Social Media Technologies to Promote Distributed Democracy and Create Digital Neighborhoods. In The Connected Community: Local Governments as Partners in Citizen Engagement and Community Building, edited by James H. Svara and Janet Denhardt, 80- 87. Phoenix, AZ: Alliance for Innovation.

National Equity Atlas. (2015). The atlas: indicators. Retrieved April 10, 2020 from https://nationalequityatlas.org/indicators?ind=32751

Newacheck, P. W., Hughes, D. C., \& Stoddard, J. J. (1996). Children's access to primary care: differences by race, income, and insurance status. Pediatrics, 97(1), 26-32. 


\section{Social Equity and COVID-19: The Case of African Americans}

Nguyen, G. C., LaVeist, T. A., Harris, M. L., Wang, M. H., Datta, L. W., \& Brant, S. R. (2010). Racial disparities in utilization of specialist care and medications in inflammatory bowel disease. The American journal of gastroenterology, 105(10), 2202.

Norman-Major, K. (2011). Balancing the Four E s; or Can We Achieve Equity for Social Equity in Public Administration?. Journal of Public Affairs Education, 17(2), 233-252.

Norris, P. (2001). Digital divide: Civic engagement, information poverty, and the Internet worldwide. Cambridge university press.

Perrett, C. (2020). Voter suppression on steroids': Wisconsin's decision to hold the state's inperson primary amid the COVID-19 pandemic will suppress voters, advocates warn. Business Insider. Accessed online.

Perry, A. and Turner, E. (2019). Smartphones help blacks, Hispanics bridge some - but not all digital gaps with whites. Pew Research Center. Accessed online.

Polednak, A. P. (1991). Black-white differences in infant mortality in 38 standard metropolitan statistical areas. American journal of public health, 81(11), 1480-1482.

Quillian, L. (2014). Does segregation create winners and losers? Residential segregation and inequality in educational attainment. Social Problems, 61(3), 402-426.

Rivera, F. G., \& Erlich, J. (Eds.). (1998). Community organizing in a diverse society. Pearson College Division.

Rehm, C. D., Monsivais, P., \& Drewnowski, A. (2011). The quality and monetary value of diets consumed by adults in the United States. The American journal of clinical nutrition, 94(5), 1333-1339.

Renauer, B. C. (2012). Neighborhood variation in police stops and searches: A test of consensus and conflict perspectives. Police quarterly, 15(3), 219-240.

Riccucci, N. M. (2009). The pursuit of social equity in the federal government: A road less traveled?. Public Administration Review, 69(3), 373-382.

Riccucci, N. M., \& Saidel, J. R. (1997). The representativeness of state-level bureaucratic leaders: A missing piece of the representative bureaucracy puzzle. Public Administration Review, 423-430. 


\section{Social Equity and COVID-19: The Case of African Americans}

Riccucci, N. M., \& Van Ryzin, G. G. (2017). Representative bureaucracy: A lever to enhance social equity, coproduction, and democracy. Public Administration Review, 77(1), 21-30.

Rice, M. F. (2004). Organizational culture, social equity, and diversity: Teaching public administration education in the postmodern era. Journal of Public Affairs Education, 10(2), 143-154.

Richardson, L. D., \& Norris, M. (2010). Access to health and health care: how race and ethnicity matter. Mount Sinai Journal of Medicine: A Journal of Translational and Personalized Medicine: A Journal of Translational and Personalized Medicine, 77(2), 166-177.

Rivera, F. G., \& Erlich, J. (Eds.). (1998). Community organizing in a diverse society. Pearson College Division.

Robinson, L., Cotten, S. R., Ono, H., Quan-Haase, A., Mesch, G., Chen, W., ... \& Stern, M. J. (2015). Digital inequalities and why they matter. Information, communication \& society, 18(5), 569-582.

Root, Danielle. (2020). Election Contingency Planning During the Coronavirus Pandemic. Center for American Progress. Retrieved from https://www.americanprogress.org/issues/democracy/news/2020/03/18/481794/electioncontingency-planning-coronavirus-pandemic/

Rothstein, R. (2017). The color of law: A forgotten history of how our government segregated America. Liveright Publishing.

Ryfe, D. M., \& Stalsburg, B. (2012). The participation and recruitment challenge. In T. Nabatchi, J. Gastil, M. Weiksner, \& M. Leighninger (Eds.), Democracy in motion: Evaluating the practice and impact of deliberative civic engagement (pp. 43-58). New York, NY: Oxford University Press.

Sabharwal, M., \& Geva-May, I. (2013). Advancing underrepresented populations in the public sector: Approaches and practices in the instructional pipeline. Journal of Public Affairs Education, 19(4), 657-679.

Schneider, J. A. (2009). Organizational social capital and nonprofits. Nonprofit and Voluntary Sector Quarterly, 38(4), 643-662. 


\section{Social Equity and COVID-19: The Case of African Americans}

Schwartz, E., Kofie, V. Y., Rivo, M., \& Tuckson, R. V. (1990). Black/white comparisons of deaths preventable by medical intervention: United States and the District of Columbia 1980-1986. International Journal of Epidemiology, 19(3), 591-598.

Smith, C. R., \& Fernandez, S. (2010). Equity in federal contracting: Examining the link between minority representation and federal procurement decisions. Public Administration Review, 70(1), 87-96.

Smith, L. P., Ng, S. W., \& Popkin, B. M. (2013). Trends in US home food preparation and consumption: analysis of national nutrition surveys and time use studies from 1965-1966 to 2007-2008. Nutrition journal, 12(1), 45.

Walsh, K. C. (2007).Talking about race: Community dialogues and the politics of disagreement.Chicago, IL: University of Chicago Press

Ward, J. D., \& Rivera, M. A. (2013). Institutional racism, organizations \& public policy. Peter Lang Incorporated, International Academic Publishers.

Wooldridge, B., \& Gooden, S. (2009). The epic of social equity: Evolution, essence, and emergence. Administrative Theory \& Praxis, 31(2), 222-234.

Woolhandler, S., Himmelstein, D. U., Silber, R., Bader, M., Harnly, M., \& Jones, A. A. (1985). Medical care and mortality: racial differences in preventable deaths. International Journal of Health Services, 15(1), 1-22.

Young, M. M. (2020). Implementation of Digital-Era Governance: The Case of Open Data in US Cities. Public Administration Review.

Zenk, S. N., Schulz, A. J., Israel, B. A., James, S. A., Bao, S., \& Wilson, M. L. (2005). Neighborhood racial composition, neighborhood poverty, and the spatial accessibility of supermarkets in metropolitan Detroit. American journal of public health, 95(4), 660-667. 